\title{
MALDIVIAN LEGAL SYSTEM: ISLAMIC INFLUENCE AND LEGAL REFORM
}

\author{
Mohamed Ibrahim ${ }^{1}$ \\ Ahmad Hidayat Buang ${ }^{2}$
}

\begin{abstract}
The Maldivian legal system as it evolved, is one that has largely being influenced by the principles of Islam as a religion. With Islam declared to be the religion of the State in the Constitution, this is further strengthened by the fact that the Constitution mandates that no laws that are in contradiction to the tenets of Islam shall be ratified in the country. This sets the fundamental principle upon which the laws of the country rests. The reforms that have taken place since the enactment of the very first Constitution of the country in 1932 has in a large way being influenced by the said principle. Taking a qualitative approach, this paper aims to shed light on how Islam came to Maldives, the extent of its influence on the legal system in the country, and the scope for further studies on the subject.
\end{abstract}

Keywords: Maldives, Islam, Maldivian legal system

\section{INTRODUCTION}

Maldives considers its Constitution to be the Supreme Law of the land. The Constitution of the Maldives, 2008 (hereafter referred to as "Maldives

\footnotetext{
1 Ph.D Candidate, Department of Shariah and Law, Academy of Islamic Studies University of Malaya, 50603 Kuala Lumpur, Malaysia, kunfunimohd@gmail.com

2 Professor, Department of Shariah and Law, Academy of Islamic Studies University of Malaya, 50603 Kuala Lumpur, Malaysia, ahidayat@um.edu.my
} 
Constitution 2008") stipulates that "Islam is the state religion". "While the Constitution denotes that Maldives is a sovereign, independent, and a democratic Republic that finds its basis in the tenets of Islam, it also stipulates that no law that comes into existence can exist in contradiction to any tenet of Islam. ${ }^{4}$ In this regards, Article 10 of the Maldives Constitution 2008 provides that- (a) the religion of the State of the Maldives is Islam. And Islam shall be one of the basis of all the laws of the Maldives, (b) No law contrary to any tenet of Islam shall be enacted in the Maldives. An analysis of this article reveals that the tenets of Islam are given extreme importance in the country and therefore no law can be enacted contrary to any tenet of Islam, which serves as the benchmark for reform.

A closer look reveals that there are two keywords i.e. "tenet" and "Islam". Literally, the word "tenet" refers to "a principle or belief, especially one of the main principles of a religion or philosophy." "For Muslims, the concept "Islam" means a way of life or a complete code of life. It provides spiritual faith, moral, ethical, social, and legal values. Believing, praying, fasting, paying zakāh, and performing hajj are the five pillars of Islam. In general, these are the tenets on which Islam is based upon and that these are different to the constitutional definition on the tenets of Islam. Accordingly, the 'tenets of Islam' are:

"The Holy Quran and those principles of Shariah whose provenance is not in dispute from among those found in the Sunnah of the Noble Prophet, and those principles derived from these two foundations." 6

According to Husnu-Al Suood ${ }^{7}$ the framer of Article 10 of the Maldives Constitution 2008 and the former Attorney General of the Maldives:

" as the religion of Islam is a national trait worthy of constitutional protection, the framers of the Constitution thought it proper to make provisions for the protection and preservation of the religion of its people. Therefore, upholding Islam is a central feature of the Constitution of the Maldives." 8

\footnotetext{
The Constitution of the Republic of Maldives 2008, Article 10 (a).

The Constitution of the Republic of Maldives 2008, Article 8, 10.

5 Hornby, A. S., \& Wehmeier, S., Oxford Advanced Learner's Dictionary (Oxford: Oxford University Press, 1995), 1231 'entry' "tenet".

6 The Constitution of the Republic of Maldives 2008, Article 274 (a).

7 Husnu Al-Suood (the former Attorney General of Maldives), in interview with researcher on 9 December 2013.

8 Al-Suood, H., The Maldivian Legal System (Male': Maldives Law Institute, 2014), 76.
} 
This thereby sets upon the State the constitutional obligation to ensure that the Republic is governed according to the fundamentals of Islam. This paper first presents the historical setting of the arrival of Islam in the Maldives which followed by the constitutional reforms which took place from 1932 to 2008. And then, the role of Islam is explained, in functioning of the three organs of the state: the government, legislature and courts. The paper ends by expounding the current practice of Islamic law with most recent development in the field: Islamic finance.

\section{CONVERSION TO ISLAM}

There are different opinions on how Islam was introduced in the Maldives. Based on these opinions, the religion may have been brought by the Arab traders, who stopped in the Maldives en route to Far East, or by a Moroccan Islamic Cleric named Abul-Barakat Al-Barbari who is widely credited in the popular Maldivian history for the conversion of Maldivians to Islam in 1153 AD. A third opinion states that Islam was brought by a Persian Islamic Cleric named Yousuf Shamsuddin. And yet another version claims that Islam was introduced in the year AD1338, by an Islamic Cleric named Abul Barakat YousufAl-Thabrazi. Prior to conversion to Islam, Maldivians were known to be practicing Buddhists. After the last Buddhist King Maha Kalaminja embraced Islam, the Maldivian subjects followed in 1153AD. From then onwards the King was known as Sultan Muhammad bin Abdullah, the first Muslim king. ${ }^{9}$

Among the three opinions, the more popular opinion is the second, which states that Islam was introduced in the year 1153 AD by Maulana AbulBarakat Al-Barbari, which is still debated by historians. The fact that the tomb of Maulana Abul-Barakat-Al-Barbari is situated in the capital city of Male' lends more credibility and reliability to this version of history. His landmarked Tomb: Medhuziyarayy exists in Male' where people used to visit daily and show respect to him as a spiritual leader of the Maldives.

No record exists when it was permitted to practice any faith other than Islam after its first inception in the Maldives. However, after the Portuguese invasion of the Maldives in 1558, and following the killing of then Sultan, the self-proclaimed ruler of the Maldives; the Portuguese king sent Christians to take charge of the Maldives and to enforce submission of the Maldivians to the king. With this invasion "the sea ran red with Muslim blood", properties were

9 Maloney, C., People of the Maldive Islands (New Delhi: Orient Longman, 1980), 99. 
seized publicly, and the people were treated harshly. ${ }^{10}$ This came to an end by the noble national hero Sultan Muhammad Thakurufan and his two brothers Hassan Thakurufan and Hussein Thakurufan, who started jihad against the Portuguese invasion. After a 17-year rule, the Portuguese quit the Maldives, and Muhammad Thakurufan became Sultan and leader of the country. This represented a pivotal time for the Maldives as Islam was revived following a lengthy period of Christian rule under the Portuguese. ${ }^{11}$

Maldivian law now prohibits citizens from practicing any religion other than Islam and requires the government to exercise control over all religious matters, including the practice of Islam. In this respect two provisions: Article 10 (a) of the Maldives Constitution 2008, which stipulates that Islam is the state religion and Article 9(d) which provides that a non-Muslim may not become a citizen of the Country are given Constitutional reference widely. In addition, Section 4(c). 5 of the Religious Solidarity Act (First Amendment) forbids all public religious practices other than Islam in the Maldives. It further restricts building and providing facilities of worship (such as church, temples, synagogues etc.) for non-Muslims in the Maldives. ${ }^{12}$ However, non-Muslims are permitted to practice their faith privately in their residences.

The issue of religious freedom and its permissibility in the Maldives was studied by the Islamic Fiqh Academy of the Maldives due to international pressure to allow religious freedom in the country. The Academy's decision was made in favour of banning the practice of religious faiths other than Islam in a sitting held on $25^{\text {th }}$ April 2010. It further proposed a ban on building of places of worship for non-Muslims in the Maldives. To arrive at this conclusion, the Academy has taken two legal grounds into account: respective Islamic provisions provided earlier in the Maldives Constitution 2008 and sadd aldhari ' $a h .{ }^{13}$ In the view of the Academy, the permissibility of religious freedom in a country such as Maldives where $100 \%$ of its citizens are Muslims will open a window for infidelity in the country which shall be blocked under the doctrine of sadd al-dharī'ah.

It is arguable that the Constitutional provisions and other relevant laws relating to Islam are not the sole basis for imposing any ban on the religious freedom in the Maldives. But there are other facts such as the people's

\footnotetext{
Maloney, C., People of the Maldive Islands, 123.

Maloney, C., People of the Maldive Islands, 198-130.

Religious Solidarity Act (Law No.8 of 2004).

Maldives Islamic Fiqh Academy, 'Maldives Islamic Fiqh Academy's Resolution No. IFA/2010/01,' http://www.islamicaffairs.gov.mv/dh//f/figh.php?pageNum rsN=1\&totalRows_rsN=13, accessed on $23^{\text {rd }}$ April 2016.
} 
determination to retain Islam as a unitary religion on one hand and the Maldivian customs on the other. In 2010, after 900 years as an Islamic nation, the Maldives witnessed its first test case when Muhammad Nazim (Maldivian) declared public apostasy. A few hours later however, he reconverted to Islam. ${ }^{14}$ There is no official record that permits practice of other faiths since the conversion of Maldives to Islam, hence no single church, temple or synagogue etc., can be found in the Maldives.

\section{THE LEGAL SYSTEM}

According to Abdullahi An-Na'im, the Maldivian Legal System is an admixture of Islamic law and English Common law and the latter has influenced the Commercial law. ${ }^{15}$ In the view of Kanul, "the current Maldivian Legal System relies on a complex combination of Common law and Islamic Shariah". ${ }^{16}$ In the observation of the researcher, ${ }^{17}$ the Maldives legal system is based on Islamic law and English Common law, where the first is widely practiced in the area of family and criminal law and the latter influences the rest of the laws of the country. ${ }^{18}$

\section{CONSTITUTIONAL REFORM IN THE MALDIVES BETWEEN 1932 AND 2008}

On $19^{\text {th }}$ March 1931 Sultan Muhammad Shamshudeen ${ }^{19}$ issued a royal decree to draft the first written constitution, the Maldives Constitution $1932 .{ }^{20}$ This decree

14 Robinson, J.J., 'Islamic Foundation calls for death sentence if apostate fails to repent,' Minivan News, http://minivannews.com/politics/islamic-foundation-callsfor-death-sentence-if-apostate-fails-to-repent-7606, accessed on 3rd July 2013.

15 Abdullahi, A., Islamic Family Law in a Changing World: A Global Resources Book (London: Zed Book Ltd., 2002), 227.

16 UN General Assembly, 'Report of the Special Rapporteur on the Independences of Judges on Lawyers,' Mission to Maldives, Gabriela Kanul (New York: United Nation, 2013), 7.

17 The researcher of this study was granted the Maldives legal Practice licence (via Licence No.11/2003) by the Ministry of Justice, Maldives on $18^{\text {th }}$ November, 2003.

18 Ibrahim, M. \& Karim, M., 'Research Guide on Legal System and Research of Maldives,' GlobaLex, http://www.nyulawglobal.org/globalex/Maldives.html, accessed on $26^{\text {th }}$ April 2016.

19 Sultan Muhammad Shamshudeen (III) is a king who ruled the Maldives from 1903 to 1934. See Maloney, C., People of the Maldive Islands, 195.

20 The Constitution of the Republic of Maldives 1998, preamble. 
indicated the prospect of Islam in the legal system as it was commanded that the Constitution should be compiled in a way that would not contradict Islamic Shariah and should also be based on old customs of the nation. Similarly, it was instructed to pay respect to International law and the protectorate treaty in existence between the Maldives and United Kingdom since 1887. With these instructions, the Sultan Muhammad Shamshudeen then created a Committee to draft the first Constitution. The drafting committee was further divided into two councils. The mandate of one council was to review the old customs of the land and the second committee undertook the responsibility to review English statutes provided by the British Government to facilitate the task of drafting. ${ }^{21}$

The British government was actively involved in the drafting of the first Constitution. Once the British Government approved the draft of the Constitution then, on $22^{\text {nd }}$ December 1932 it was proclaimed as the first Constitution of the Maldives by the Sultan Muhammad Shamshudeen (hereafter referred to as “Maldives Constitution 1932"). ${ }^{22}$

According to Ameen, ${ }^{23}$ the first Constitution was based on English Common law and the Egyptian Constitution. Therefore, it can be assumed that where the basic framework of the first Constitution was based on the local customs of the Maldives, English Common law and those provisions pertaining to Islamic Shariah were borrowed from the Egyptian Constitution.

The Maldives Constitution 1932 contained 92 provisions which dealt with transformation and codification of the administrative duties of government, treaties and conventions and local customs that were practiced for ages. In the first provision of the first Constitution of the Maldives, it was stated that Maldives was a country under the British protectorate from 1887, but has authority to govern the domestic affairs of the land. This autonomy was given by the British after adoption of the Maldives Constitution 1932.

The provision relating to Islam under the Maldives Constitution 1932 was provided under the Article 3 and it said that Islam was the official religion of the country. This Article remained in all the subsequent Constitutions that were formulated in the Maldives. However, the wording of the provision was changed in the Constitution formulated in 1968. Under the Maldives Constitution 1968, Islam was the state religion and the provision remained the

21 Ameen, M., Dhivehi Rajjeyge Qanun Asasige Hayath (Maldivian Constitutional History) (Male': Novelty Printers \& Publishers, 1970), 9.

22 The People's Majilis, Dhivehi Rajjeyge Qanuni Hayath (The Maldivian Legal History) (Male': The Parliament House, 1981), 119.

23 Ameen, M., Dhivehi Rajjeyge Qanun Asasige Hayath (Maldivian Constitutional History), 15. 
same in all subsequent Constitutions and amendments under Article 7 of the Maldives Constitution 1998 and under Article 10 of the current Constitution: the Maldives Constitution 2008.

The Maldives was governed under the Maldives Constitution 1932 for 7 years and it was then abolished on $30^{\text {th }}$ June 1940. According to Ameen, the first constitution was abolished because of the passage of huge amounts of laws that were impractical to implement. ${ }^{24}$ Apart from this, some of these laws were not passed on the retrospective effect on one hand and certain legislation made the basic necessity of the people as illicit on the other hand. ${ }^{25}$

Thereafter, the country was without a written Constitution for nearly 2 years. A second Constitution was promulgated on 23 ${ }^{\text {rd }}$ April 1942 which was based on total 17 provisions ("the Maldives Constitution 1942"). Since then the Maldives has never been governed without a written Constitution. ${ }^{26}$ In 1952, Maldives decided by a public referendum to abolish the monarchy and adopt the republican system as a form of government. With this decision, the Constitution was changed to facilitate the republican system in the Maldives and adopted a new Constitution on $1^{\text {st }}$ January 1953 ("the Maldives Constitution 1953") with a total of 30 provisions. After nine months of being governed under a republican system, on $21^{\text {st }}$ August 1953, Maldives adopted the monarchy system again which was brought on by a coup. With this change, the Constitution was changed again and a new Constitution with total 80 provisions was adopted on $7^{\text {th }}$ March 1954 ("the Maldives Constitution 1954 "). ${ }^{27}$ The Maldives was then governed by a monarchy under the Maldives Constitution 1954. The Maldives then decided by another public referendum to re-adopt the republican system in the Maldives. This resulted in a change in the Constitution yet again, and a new Constitution was adopted on $11^{\text {th }}$ November 1968 ("the Maldives Constitution 1968”), which contained 86 provisions. ${ }^{28}$

On $29^{\text {th }}$ November 1980 another Constitutional reform-movement began. ${ }^{29}$ This reform was prompted with the hope of changing the government system to

\footnotetext{
24 Ameen, M., Dhivehi Rajjeyge Qanun Asasige Hayath (Maldivian Constitutional History), 15.

25 Ameen, M., Dhivehi Rajjeyge Qanun Asasige Hayath (Maldivian Constitutional History), 15.

26 The People's Majilis, Dhivehi Rajjeyge Qanuni Hayath (The Maldivian Legal History), 120.

27 The People's Majilis, Dhivehi Rajjeyge Qanuni Hayath (The Maldivian Legal History), 21.

28 Constitution of the Republic of Maldives1968, Preamble.

29 Constitution of the Republic of Maldives 1998, Preamble.
} 
establish a more comprehensive system of laws. The Constitution that resulted out of these reforms came into effect on $1^{\text {st }}$ January $1998,{ }^{30}$ and contained 156 provisions ("the Maldives Constitution 1998") and was governed for 5 years during which time immense political pressure was created to pave the way for major and landmark reforms that led to the creation of the Maldives Constitution of 2008.

\section{MALDIVES CONSTITUTION 2008}

The present Constitution of the Maldives came into force on $7^{\text {th }}$ October 2008. This was the latest constitutional reform initiated to establish a multiparty democracy in the country. This action resulted from great pressure both domestically and internationally. On $9^{\text {th }}$ June 2004, then President Maumoon Abdul Qayyoom announced his political reform agenda. ${ }^{31}$ President Qayyoom proposed that a Special Majlis (Constitutional Review Assembly) be created under Article 94 of the Maldives Constitution 1998. The purpose of this reform was to create a democratic form of governance that would be based on three separate branches i.e. Executive, Judiciary and the Legislature. Within this democratic model, the Maldives Constitution 2008, containing 301 provisions and three schedules, was adopted.

It is worth noting the salient features of the Constitution of the Maldives summarised below:

\section{Islam as a System}

Article 2 of the Maldives Constitution 2008 declares that the country is based on Islamic principles. In general, all rights, duties, responsibilities, and eligibilities for public posts provided in the Constitution are subject to the tenets of Islam. For example, fundamental rights under the Constitution are granted to the extent not contradictory with the Islamic norms. With regards to the duties and responsibilities of the public office holder, they shall be sworn to respect the religion of Islam as provided in the respective oaths of various office holders in Schedule 1 of the Constitution. These are: oaths of the President, Vice President, Members of the Parliament, members of the Cabinet, Judges, and members of the Independent bodies. Likewise, for eligibility to all Public Posts qualification and candidacy is also stipulated on the basis of Islamic

\footnotetext{
30 Constitution of the Republic of Maldives 1998, Preamble.

31 The Commonwealth Secretariat Website, 'Commonwealth Country ProfileMaldives,' http://commonwealthofnations.org/yb-pdfs/maldives_country_profile. pdf, accessed on 23 $3^{\text {rd }}$ April 2016.
} 
conditions. These include that all public office holders must be Muslim and followers of Sunni Islam. Likewise, office holders shall not be convicted of any offences prescribed in Islam as hudüd.

\section{Democratic Republic}

Article 2 of the Maldives Constitution 2008 stipulates that the Maldives is a democratic republic and Article 4 of the Constitution provides that all the powers of the State are derived from, and remain within, the Citizens. Democratic norms are core values of all principles laid down in the Constitution. The main purpose for the reform of the Maldives Constitution 1998 was to transit the country from autocratic rule to a democratic system of governance. To guarantee these democratic norms, the Constitution sets out mechanisms and a framework to protect and safeguard democracy by creating independent institutions such as a Human Rights Commission; Anti-Corruption Commission; Election Commission; Auditor General and Prosecutor General etc.

\section{Separation of Power}

The separation of three organs of the state in the Maldives is confirmed under the Constitution. Article 5 of the Maldives Constitution 2008 stated that all legislative powers are vested in the Majlis. Article 6 provides that executive power is vested in the President; and judicial power is vested in the Courts under Article 7 of the Maldives Constitution 2008. These powers were previously held by the President under past constitutional regimes.

\section{Fundamental Rights}

The Constitution guarantees rights to all persons in a manner that these rights are not contrary to any tenet of Islam. The rights and freedoms are contained in Chapter II of the Constitution (Articles 16-69). It is a State duty to ensure, protect, and promote the rights and freedoms outlined in Chapter II. Under this Chapter, there are 50 rights stipulated and defined. These are based on a universally accepted bill of rights as long as they are not contrary to the tenets of Islam. For example, Article 19 provides that a citizen is free to engage in any conduct or activity that is not expressly prohibited by Shariah or by law. Likewise Article 27 stipulates that freedom of expression is limited to that extent which is not contrary to any tenet of Islam. With respect to the right to education it is included that education shall strive to inculcate obedience to Islam, instil love for Islam under Article 36. 


\section{Flexible}

Pursuant to Article 92 of the Maldives Constitution 1988, to amend, change, and repeal the Constitution is a discretionary power of the Constitutional Review Assembly formed under Article 93 of the Maldives Constitution 1998. This body shall be comprised of cabinet ministers, members of Parliament, eight members appointed by the President and two elected members from each parliament constituency. Any amendment and repeal of the Constitution shall be commenced by the President through his order to create the Constitutional Assembly, under Article 94 of the Constitution.

Historically, the process of the Constitutional review is a lengthy procedure in the Maldives. For example, for the Maldives Constitution 1998, the reform was initiated in 1980 and continued on for 17 years before being completed in 1998. Similarly, the 2008 constitution reform was commenced in 2004 and ended in 2008. This long process was made more simple and flexible under the present Constitution. Under Article 261 of Maldives Constitution 2008, the Constitution can be amended by the Parliament itself, by a bill passed by three quarters majority of the total members of Parliament. As a result, the long process of Constitutional reform came to an end and abolished by way of incorporation of provisions relating to Constitutional Review Assembly for the amendment and reform of the Constitution.

\section{Supremacy of the Constitution}

According to Article 8 of the Maldives Constitution 2008, supremacy is vested in the Constitution. It states: "the powers of the State shall be exercised in accordance with this Constitution." Similarly, Article 268 of the Maldives Constitution 2008 provides that all laws must be enacted in accordance with the Constitution. Any law or part of any law is inconsistent with the Constitution is, to the extent of its inconsistency, be void and of no force and effect. The obligations imposed by the Constitution must be fulfilled. Any conduct contrary to the Constitution shall be invalid. This concept is derived from the practices of other Common law countries.

The present-day Constitution differs from previous Constitutions in several aspects. These include: universally recognized and accepted democratic tenets, especially freedom of expression; the establishment of political parties etc.

The independence of the judiciary and other institutions are confirmed under the Maldives Constitution 2008 to facilitate multi-party democracy in Maldives for the first time in its history. All rights and privileges are also subject to the tenets of the Islam. In general, the present Constitution anchored 
itself more closely in accordance with Shariah and Islam when compared to previous Maldives constitutions.

If we consider constitutional reforms undertaken from 1932 to 2008 in relation to Islamic law, the only significant change is in the current Constitution as explained earlier. In the Maldives Constitution 1932 Islam was declared the official religion. This provision essentially remained unchanged in the subsequent constitutions. With regards to Islamic law, it was mentioned that adjudication shall be based on "Shariah and Law" only without any further description. However, the amendment made to the Maldives' Constitution 1932 on $5^{\text {th }}$ July 1934 amalgamated a new provision in connection with the Islamic law and judicial independence. Within Article 73 of the Maldives Constitution 1932 the Chief Justice oversaw Islamic law enforcement and religious duties.

Another example, by the Maldives Constitution 1968, which introduced a remarkable change under Article 32 in comparison to the previous Constitution in terms of implementation of the Islamic law. Here, a provision stipulated that the head of the religion would be the President. The title used was "Preacher of Islamic Shi 'ar". This provision was subsequently included in the Maldives' Constitution 1998 under Article 38. Apart from this, under the Maldives Constitution 1998, it was provided that the President served as the head of Judiciary $^{32}$ and held absolute authority to appoint and dismiss judges including the country's Chief Justice..$^{33}$ As there was no Supreme Court, the High Court served as the highest Court of Appeal in the country and against the decisions of this Court, appeal could only then be referred to the President.

The Maldives Constitution 1998 provides equal status to law and Islamic Shariah by defining the law as those laws that were passed by the Parliament and the Islamic Shariah. ${ }^{34}$

\section{FORM OF GOVERNANCE AND POLITICAL SYSTEM}

Until 1968, the Maldives had been a Sultanate except for a limited period during the Colonial era under the Portuguese. Maldives Royal Succession Customs is based on hereditary rights over the throne. This was superseded under the Maldives Constitution 1932 in relation to provision of succession. The foundation of the Sultanate was laid down with the arrival of Islam. Sultan

The Constitution of the Republic of Maldives 1998, Article 39.

33 The Constitution of the Republic of Maldives 1998, Article 112.

34 The Constitution of the Republic of Maldives 1998, Article 156. 
Muhammad Bin Abdullah was the first Sultan under whom the Maldives embraced Islam and the last Sultan was Sultan Muhammad Fareed Al-Awwal..$^{35}$

Traditionally, the Sultan holds royal, administrative, and religious duties. With the amendment of the Maldives Constitution 1932, the duties of the Sultan as the head of the government were terminated. These duties were transferred to the Prime Minister and his cabinet. The Islamic duties remained with the Sultan as the Head of the State. However, in the first amendment made to the Maldives Constitution 1932 in 1934, some of the religious duties were transferred to the Chief Justice as explained earlier. During the Sultanate era, the system of the government was a federal form of government and was controlled from the Capital City, Male'. The authority and responsibilities of the local administration were given to appointed representatives of the Sultan. For this, in each Atoll, there was an atholhuverin (Atoll's Chief). Atholhuverin used to report directly to the Sultan. In each island, there was an Island Chief, known as kathyb appointed by the Sultan who used to report to the atholhuverin. The original word of kathyb was from al-khathib who usually leads Friday prayer. In addition to these two appointees, there was a mudhim in each inhabited island appointed by the Sultan whose responsibility was to call for prayers five times a day, and to lead prayers and administer funeral rituals. ${ }^{36}$

The transformation of the country from a Sultanate to a Republic on $1^{\text {st }}$ January 1953 did not make a significant difference except for the abolishment of the monarchy in terms of governance. The Head of State since then was the President who was elected by the people. He was also the Head of the Government by holding the position of Prime Minister, and other five portfolios such as external affairs, internal affairs, national security, treasury, and health. The adopted republican system was based on a parliamentary system. The parliament featured two houses: upper house and lower house. The lower house consisted of 38 members where two members were elected from each atoll. The upper house consisted of 9 members elected by the lower house and 9 members appointed by the President. All laws were passed by the upper house. Although the President used to hold certain cabinet posts who was not a Member of Parliament, the main selection of Cabinet ministers was done by the lower house in principle. ${ }^{37}$

As explained earlier, the first republic lasted for nearly 9 months and thereafter the monarchy was restored. This continued until the establishment

35 The Constitution of the Republic of Maldives 1998, Article 156.

36 Maloney, C., People of the Maldive Islands, 184.

37 Ameen, M., Dhivehi Rajjeyge Qanun Asasige Hayath (Maldivian Constitutional History), 150. 
of the second republic in 1968. With the second republic, the monarchy was re-abolished and the Republic restored. Since then the Maldives has remained a republic until today. There were some prerogative changes made in the Maldives Constitution 2008. The introduction of political parties represented a significant change when compared to previous regimes as well as a creation of the government which finds its basis in the principle of separation of powers. With these new changes, Presidential powers over the Judiciary and Legislature came to an end. Executive power is vested in the President who is elected by popular vote. His duties and responsibilities are assigned to his cabinet and representatives at national level under the Article 115 of the Maldives Constitution 2008 and at the local level to local councils as provided under Article 233.

Another significant change made within the current system was that local councillors be elected by direct vote of the respective communities. The Maldives local councils follows a three-tier system. Firstly, at the national level, there is the local government authority, which is a statutory body set up under the section 62 of the Decentralization Act (Law No. 11 of 2010) to oversee the council affairs. Secondly, there are City Councils and Atoll Councils, created under sections 21 and 12 of the Act. These councils are elected by popular vote in respective atolls and cities. Each council has the mandate to administer the local affairs in its respective atolls and cities. Thirdly, in each inhabited island, a council is elected to govern their districts, and these island councils are elected by residents of those communities.

The executive departments within the government such as ministries, local councils and the state bodies are empowered to create regulations for administrative issues. The autonomy is confirmed under the relevant legislation. Previously, all government orders were considered as equal, having the statutes of law that held legal power. Any violations of these orders carried with it threats and penalties of prosecution under Section 88 of the Penal Code (Law No.1 of 1966). ${ }^{38}$ It is also worth noting that Presidential Decrees were also considered as law. With the amendment of the Maldives Constitution 2008 , the violation of an executive order is no longer considered an offence. All orders are subject to the tenets of Islam. If such orders contradict any tenet

38 The provision reads, "..it is an offence to disobey an order issued lawfully with in the Shariah or law, person guilty of this offence shall be subjected to a punishment of exile or imprisonment or house detention not exceeding MVR150.00..." This provision used to be charged as any illegal act which is not specifically provided in law or Shariah. The provision was repealed with the new Penal Code (Law No.9/2014), as all offences and penalties are clearly stated. 
of Islam, the matter may be referred to the Court of law under the Article 43 of the Maldives Constitution 2008.

\section{THE LEGISLATURE}

Law making power is vested in the parliament known as the "People's Majlis". ${ }^{39}$ Parliament is comprised of members elected by the people for a period of 5 years with a total numbers of 77 seats. The Majlis comprised of members elected by 20 Atolls and the Capital Male as listed in Schedule I of the Constitution in a ratio of one member for each five thousand people.

The legislative history of Maldives began with the creation of its first Constitution, the Maldives' Constitution 1932. Since then laws have been enacted by a parliament. Prior to this time all laws were made by the King himself, and no mechanism existed that could challenge the King's edicts on any basis, whether Islamic, or otherwise. ${ }^{40}$

Principles laid down under the Maldives Constitution 1932 for law making were very brief. There were few provisions in this respect. The laws had to be based on the Constitution and respecting any treaty in force between the Maldives and the British government. It further provided that laws should not be enacted with retrospective effect, and should be gazetted after having the royal assent. On the basis of these guidelines, the first 40 laws that were passed by this Parliament were mainly basic brief legislations relating to governmental administration and taxation. Additionally, there was scant legislation related to law enforcement and the Judiciary. Amongst this legislation there was "The Law on Learning the Holy Quran, Arabic and Dhivehi Letters", which outlined proper Islamic teachings. Another legislation of note centred on the enforcement and punishment for adultery, which contained provisions on the offences relating to Zina.$^{41}$ It was found that the legislating rules first laid down under the first Constitution (Maldives Constitution 1932) was inherited by all successive Constitutions in the Maldives. However, the rule relating to honouring the British protectorate treaty was abolished from those Constitutions adopted after independence in 1965.

Under Article 70 of the Maldives Constitution 2008, the Majlis is empowered to amend the Constitution, to enact and repeal laws, and other

\footnotetext{
39 The Constitution of the Republic of Maldives 2008, Article 70(a).

40 Al-Suood, H., The Maldivian Legal System, 9.

${ }^{41}$ Ameen, M., Dhivehi Rajjeyge Qanun Asasige Hayath (Maldivian Constitutional History), 43.
} 
duties as prescribed under the Constitution. However, in doing so, it should not violate any tenet of Islam or Shariah principles. ${ }^{42}$

There are secondary legislations in the Maldives. Under Article 94 of the Maldives' Constitution 2008:

"The People's Majlis may, pursuant to law and for prescribed purposes, delegate to any person or body the power to make orders, and regulations, or other instruments having legislative effects, including the power to:

a) Determine a date on which any law shall come into or cease to have effect;

b) Make any law or part thereof applicable to any area or to any class of persons."

Under the provisions government departments and statutory bodies are permitted to make regulations as per their respective legislations. For example, under Section 105 of the Companies Act (Law No. 10 of 1996) the Ministry of Economic Development and Trade is permitted to make regulations on corporate affairs. Likewise, under Section 15 of the Consumer Protection Act (Law No.1 of 1996), the same Ministry is given the mandate as a regulator. These regulations are by nature like administrative orders issued for the convenience of followers as a regulator. Some pieces of legislation had provisions that created regulations on specific issues, whereas in others a wider scope of enactment was authorized. The limits of these regulations extended to specific powers granted in the legislation.

Under Article 115 of the Maldives Constitution 2008, the President is entrusted with the power to issue executive orders. This autonomy is vested in the President in separate legislation.

Apart from these examples, as per common law tradition, judges develop laws by way of judicial pronouncement i.e. precedents. Whether it is a regulation, a precedent or an executive order, all are subjected to Islamic tenets.

To conclude this segment, it is important to mention that all laws passed by the Majlis are in the local Dhivehi language, with an English translation produced by relevant authorities, subjected to the Attorney General's approval. In the event of any conflict between the original legislation and its translation, the original version in Dhivehi language will prevail.

42 The Constitution of the Republic of Maldives 2008, Article 70.(c). 


\section{THE COURT SYSTEM}

Judicial power is vested in the Courts as provided in the Article 7 of the Maldives Constitution 2008. There exists a three-tier court system: the Supreme Court, which is the highest court of the land, headed by the Chief Justice. Under the Supreme Court is a single Court of Appeal. Below the appellate court the judiciary divides into two categories: Superior Courts and the Magistrate Courts. In terms of location, the Superior Courts can only be established in the Capital Island Male' as provided in section 53(b) of the Judicature Act 2010 (Law No.22 of 2010). Whereas in each of the inhabited islands there shall be a Magistrate Court under section 62 of the Judicature Act (Law No.22 of 2010). Accordingly, the total numbers of courts in the Maldives are 198. Out of these, 191 are magistrate courts; five are superior courts and the two upper courts: The Supreme Court and High Court. ${ }^{43}$

The jurisdiction of the Magistrate Courts oversees what are described as petty matters (i.e. in relation to the family, hudūd, Criminal and Civil matters) and have territorial jurisdiction within the island where each court is located. Initially, authorities contended creating Magistrate courts in all inhabited islands - 191 in all - which would not have been feasible, and a waste of resources. However, these Magistrate Courts were established for the convenience of people to have access to justice. Travelling by sea to another island to file a petition would be a burden both physically and financially unless these courts were present.

The five superior courts comprise the Family Court, Criminal Court, Juvenile Court, Civil Court and Drug Court. Among these, the Criminal, Juvenile, and Drug courts manage all criminal matters. The Criminal Court holds jurisdiction in the most severe criminal offences: these include homicide, fraud, terrorism, and $h u d \bar{u} d$ offences as well as issues relating to fiscal matters. In addition to settling these type of cases, the court holds authority to mete out penalties and punishments. Juvenile Court deals with underage offenders below age 18; the Drug Court serves as a special court dedicated to hearing narcotics, or drug-related offences, and enforcing the law stipulated in Section 30 of the Narcotics Act (Law No. 17 of 2011). The Family Court deals with family matters except in those cases involving inheritance. Inheritance matters and other civil, and commercial matters are dealt with by the Civil Court.

43 Department of Judicial Administration Maldives, 'Justice Statistics Report,' http:// judiciary.gov.mv/viewer.html?file=/documents/Statistics/2014/2014draft.pdf, accessed on $26^{\text {th }}$ Aril 2016. 
The two higher courts - the Supreme Court (hereafter referred to as "SC") and the High Court act as Courts of Appeal. Against the decision of the lower Courts, appeal can be referred to the High Courts and against the decisions of the High Court a person can appeal to the SC. The decisions of the higher Court are binding on the lower courts. The decision of the SC, which also acts as the guardian of the Constitution, is final.

The appointment of judges are within the mandate of the Judicial Service Commission, a statutory body set up as per Article 157 of the Maldives Constitution 2008. The selection criteria for judges are mainly based on Article 149 of the Maldives' Constitution 2008, which stipulates on the faith, qualification and character of the prospective candidate.

Taking these criteria into account, and the fact that the Maldives is a hundred percent Sunni Muslim nation, the Maldives Constitution 2008 dictates that all judges shall be Sunni Muslims. Glaringly, the constitution does not indicate whether judges must also be Maldivian citizens, hence it can be inferred that a foreigner could serve as a judge in the Maldives. Currently, there is no sitting foreign judge but history shows that the Maldives had foreign Muslim judges in the early days of Islam. ${ }^{44}$ Next, with regard to qualifications, it is stated that a basic law degree or Shariah degree is sufficient. This can be referred to as one area where the Constitution guarantees equal status to Shariah and the law. With regards to the character of the applicant, the Constitution makes difference between a person having a criminal record on a Shariah offence and that of the criminal law of the country. If a person has a record of a prior hudūd conviction, then that person is disqualified for life from serving as a judge. However, if a person has a non-hudūd-related offence on his record, he may apply for a judgeship after five years from the completion of his sentence.

There are a few quasi-judicial bodies in the Maldives. Such as the employment tribunal, which decides labour matters and the tax tribunal, which has the mandate to review tax-related matters. The decisions of both these bodies can be referred directly to the High Court. ${ }^{45}$

The courts are bound to apply Islamic Shariah when the Constitution or law is silent on any particular matter. Every court has the jurisdiction to overturn the decision of a lower court, likewise lower courts are obliged to follow the decisions of a higher court. ${ }^{46}$

44 Maloney, C., People of the Maldive Islands, 288.

45 Ibrahim, M. \& Karim, M., 'Research Guide on Legal System and Research of Maldives,' GlobaLex, http://www.nyulawglobal.org/globalex/Maldives.html, accessed on $26^{\text {th }}$ April 2016.

46 The Constitution of the Republic of Maldives 2008, Article 142. 


\section{ISLAMIC LAW IN PRACTICE}

The meaning of Islamic law is derived from all Sunni Schools of law, rather than restricting it to one school in relation to judicial matters under the Maldives Constitution 2008. ${ }^{47}$ However, for purposes of worship and other religious duties, Maldivians are followers of the al-Shafi' $\overline{1}$ school.

The Ministry of Islamic Affairs serves as the regulatory body over religion in the Maldives. ${ }^{48}$ The Ministry possesses a mandate to apply the force of law over all legislation and regulations within its purview. In this respect the key legislation is the Religious Solidarity Act (Law No.6 of 1994), which came into force on $4^{\text {th }}$ July 1994. Its central purpose is to eliminate Islamic Religious extremism and to keep mainstream Islamic teachings and Fatwas. The Act decrees that all Maldivians are followers of one religion and one School of law without referring to any religion and School of law, the madhhab. However, this creates no confusion in practical terms as the Maldives is a $100 \%$ Islamic country and its citizens are followers of the al-Shafi' 1 school. Section 2 of the Act stipulates that the Islamic Teaching, Preaching and Issuance of any Fatwas may be decreed by authorities who are permitted under the Act. The issuance of this permit is based on educational qualifications. The qualification as specified is a recognized degree by the government of the Maldives. A list of recognized universities is provided under the Regulation on Religious Solidarity. ${ }^{49}$ The regulation also provides general guidelines for Islamic teaching for teachers and clerics. Section 4 of this Regulation sets out seven principles in this respect. An analysis shows that on the issuance of a Fatwa, there exists no requirement to maintain the view of the al-Shafi' 1 school but rather the view of majority of ulama' are acceptable. In addition to this, under point 4 of this principle, it is contained that those who teach and preach Islam shall keep in mind religious 'urf while doing so, although ' urf was never explained.

All mosques belong to the state and are maintained by the Ministry of Islamic Affairs. The Imams of the mosques are employees of the Ministry. Performance of Friday prayers and sermons are guided by the Ministry. Friday sermons are provided to the Imams and they are strictly bound to follow the text provided by the Ministry. ${ }^{50}$

\footnotetext{
47 The Constitution of the Republic of Maldives 2008, Article 274.

48 Religious Solidarity Act, First Amendment (Law No.8 of 2014), section 2.

49 Ministry of Islamic Affairs, Ministry of Islamic Affairs' Regulation No. 2011/R-40 (Male': Ministry of Islamic Affairs, 2011).

50 Religious Solidarity Act, First Amendment (Law No.8 of 2014), sections 3-4.
} 
Amongst the religious duties monitored by the Ministry are Ramadān (fasting), zakāh (alms), and hajj (pilgrimage). With regard to fasting during Ramadān, all restaurants and cafes must remain closed in all inhabited islands during daytime hours and eating in public is prohibited. Section 616(a) of the Maldives Penal Code (Law No. 9 of 2014) considers eating publicly during the month of Ramadan as an offence punishable by law. With regards to zakāh, collection of zakāh and distribution is managed by the Ministry. ${ }^{51}$ Lastly, in respect to hajj (pilgrimage), a significant reform was taken on $16^{\text {th }}$ May 2013 by the creation of the corporate body: Maldives Hajj Corporation Ltd by the government. This company is state-owned, and exists with the objective of facilitating affordable hajj and 'umra pilgrimages for all Maldivian citizens. ${ }^{52}$

A recent amendment to the Maldives Religious Solidarity Act (Law No.6 of 2016) was designed to establish a Maldives Supreme Fatwa Council for the replacement of the Maldives Islamic Fiqh Academy as an umbrella body of the Ministry of Islamic Affairs, which is composed of 5 members. The members are appointed by the President, a selection based on a nominee list from the Minister of Islamic Affairs. The list of nominees includes a sitting judge as nominee of the Chief Justice of the Maldives; a nominee from the Maldives Islamic University, and two nominees by the President of the Maldives. The head of the Council and his deputy are appointed by the President. The mandate of the council remained the same as the function of the Maldives Islamic Fiqh Academy and their findings are voluntary. The only change made by the new amendment was the renaming of the Islamic Fiqh Academy as the Maldives Supreme Fatwa Council. The council is yet to be formed and its complete mission is unclear. ${ }^{53}$ Thus, it would be advisable for future reforms to adopt the Malaysian model of the Fatwa council with modifications suitable for the Maldives as a unitary state for the formal recognition of fatwas.

Islamic law practices today can be seen in areas of family, inheritance, criminal, and evidence law. The codified family law originated from the al-Shafi' 1 School of law. ${ }^{54}$ All marriages should be registered within the

51 See discussion on potential reform in the area of the zakāh management in Chapter 5.2.7.

52 Maldives' Hajj Corporation's website, http://mhcl.mv/about, accessed on $28^{\text {th }}$ April 2016.

53 The bill ratified on $25^{\text {th }}$ April 2016. For the view of the amendment, available at http://www.mvlaw.gov.mv/pdf/ganoon/chapterII/6-2016.pdf

54 Nasheed, A.M., 'Salient Features of the Maldivian Family Law,' Maldives Law Review, 1 (2013), 17-28. 
proper court of the law. ${ }^{55}$ Unlike some Islamic countries, the marriage 'urufi (customary) is not permitted. The proper courts of law are Family court and magistrate courts for purposes of marriage-related matters. Divorce, or the dissolution of marriage petitions can be filed by both partners. ${ }^{56}$ The divorce, talāq shall be taken place before the court of law. Any dissolution of marriage outside the sanction of the court is considered an offence. Either party who wishes to dissolve the marriage or talāq shall submit an application in the relevant court. Once such an application is received, the matter initially will be referred to the counseling department of the Court for reconciliation of the couple. For this, the period is three months. If the court finds that during the reconciliation period, the couple are not in a position to reconcile, then with the permission of qadi, the husband may recite the tala $q$ before the Court. In the case of wife, the dissolution petition is occasionally treated as a khulu'or a fask $h$ case. ${ }^{57}$ Polygamy is permissible but with some restrictions following a financial capability assessment of the husband..$^{58}$

In criminal law, the police investigates crimes and the Prosecutor General issues state charges for the offence. The meting out of punishment rests on the Ministry of Home Affairs except in hudūd cases, which are enforced by the Court itself before the qadi.

As discussed earlier, in the salient features of the Maldives Constitution 2008, for the eligibility to various public posts, the candidate must not have a conviction of any hudüd offence. The SC interpreted the meaning of this provision as any person who has been charged with any hudüd offence as provided in Islamic law, regardless of being convicted or sentenced as a hudūd punishment. In other words, the offence of sariqah (theft) is an offence prescribed in the Quran, though the actual punishment is neither pronounced, nor applied in the Maldives. Thus, a person who has been convicted of theft will be barred from holding a public post in the Maldives. ${ }^{59}$

Hudūd offences are those specified in the Quran and Sunnah. The Quran decreed four offences, namely fornication, theft, slanderous accusation, and highway robbery. Two additional offences-alcohol consumption and apostasy-

\footnotetext{
$55 \quad$ Maldives Family Act (law No. 4 of 2000), section 3.

56 Maldives Family Act (law No. 4 of 2000), sections 23-24.

57 Maldives Family Act (law No. 4 of 2000), sections 23-24.

58 Maldives Family Act (law No. 4 of 2000), section 12.

59 Aseeth Thaufeeq v. Maldives Election Commission [2011/SC-E/07].
} 
are covered in Islamic law. Mutiny is considered by some as a hudūd offence, which makes the total number of hudūd offences as seven. ${ }^{60}$

In practice, fornication and drinking alcohol are the only offences charged and punished in the Maldives as prescribed in Islamic law. Yet the penalty provided for adultery: rajm (stoning) in Islamic law is not executed, however, 80 lashes and house arrest as $t a{ }^{\prime} z \bar{r} r$ are practiced. ${ }^{61}$ This practice has not been changed even with the implementation of the new penal code: the Maldives Penal Code (Law No.9 of 2014). The only noticeable reform was the re-writing of past practices, and offences relating to Islamic law. Nevertheless, section 1205 of the Code stipulates, notwithstanding offences relating to hudūd and qișās, shall be punishable as prescribed by Shariah. ${ }^{62}$ Despite the said provision regulating these offences, and the open declaration of Shariah serving as the supreme authority, the penal code is generally most relied on in these cases. Yet the provision grants autonomy for judges in the application of Shariah in matters presented to them as provided in section 1205 of the Code.

With respect to the law of evidence, the Evidence Act 1976 (Law No. 24 of 1976) came into force on $23^{\text {rd }}$ September 1976. This is a focused piece of legislation concerning evidence. Article 7 of the Act provides that all legal procedures are governed by the Act itself, except in cases where the Quran prescribes certain offences be proved in a particular manner. The Act does not state the offences as provided under the Quran. Another piece of legislation concerning the testimony of women is the Women Testimony Act 1972 (Law No.14 of 1972), which came into effect on $18^{\text {th }}$ April 1972. This very brief Act contains only one provision, which stipulates that a woman's testimony stands equal to a man's, unless otherwise determined in the Quran.

Regarding inheritance, the Inheritance Claims Act (Law No. 25 of 1975) came into force on $10^{\text {th }}$ November 1975 . This law serves as a procedural law containing a provision stipulating that all inheritance claims be submitted within 60 days after death.

In inheritance matters, the Maldives follows Islamic Inheritance law except in certain land cases. Currently, inheritance remains 'uncodified', and follows a brief regulation made by the relevant court.

${ }^{60}$ Kamali, M. H., 'Are the Hudud Open to Fresh Interpretation?' Islam and Civilisational Renewal (ICR), 1/3 (2010).

61 Al-Suood, H., The Maldivian Legal System, 114-115.

62 Maldives Penal Code, Third Amendment (Law No.26 of 2015). 


\section{ISLAMIC FINANCE}

In general, the regulatory framework for Islamic finance is the same framework used by conventional finance. The main regulatory body in respect to banking, finance leasing, and insurance industries is the central bank: the Maldives Monetary Authority (hereafter referred to as "MMA"). And the capital market regulatory body is the Capital Market Development Authority (CMDA).

The Maldives Banking system follows dual Islamic and conventional systems. Two, full-fledged Islamic financial institutions operate in the country: the Maldives Islamic Bank (MIB) and the Amana Takaful. There are also three institutions that have Islamic Windows which are the Bank of Maldives (BML), the Housing Development Finance Corporation (HDFC), and the Capital Market Development Authority (CMDA). ${ }^{63}$

With respect to Islamic banking, the Maldives Islamic Bank, began operations officially on 14 March 2011 as a result of an agreement between the Islamic Corporation for the Development of the Private Sector (ICD) and the Government of the Maldives. ${ }^{64}$ The bank offers various deposit and financial products. The Maldives Islamic Bank Annual Report (2011) shows that from among the products offered, the most popular products are murabahah and Istisna'. ${ }^{65}$

BML was recently granted a license to operate an Islamic window. BML offers various Islamic facilities in personal and business banking. All business products were targeted to mainly marine and tourism sectors. ${ }^{66}$ Ironically, even

63 Maldives Monetary Authority, 'Maldives Monetary Authority,' www.mma.gov. mv, accessed on 22 June 2013.

64 Maldives Islamic Bank Pvt. Ltd., Maldives Islamic Bank Annual Report. (Male': Maldives Islamic Bank Pvt. Ltd., 2011), 9.

65 There are variety of facilities offered by the Maldives Islamic Bank. These include, under the individual deposit facility; the Current account, the Savings Account and the General Account. In addition to this, for the individual financing; motor bike leasing, Consumer Goods, Murabahah General Asset Financing, and Construction Material Financing. In business facilities, includes; for deposit; Current Account, General Account Investment. There are certain facilities for business finance also; such as letter of Credit-LC, Shipping Guarantee, Murabahah General Assets, Murabahah Vessel Finance, al-Istisna '(Project Financing) and Guarantee Financing. See Maldives Islamic Bank's website, http://www.mib.com.mv/, accessed on 22 June 2013.

66 Bank of Maldives, 'Islamic Banking,' Bank of Maldives' website, https://www. bankofmaldives.com.mv/islamic-banking, accessed on 23 July 2014. 
though most of the economic investments result from the tourism and marine sectors, Islamic banks often are reluctant investors in these areas because these industries often include the non-halal trade of pork and liquor.

Sheikh Fayyaz Ali Maniku, member of the Shariah Committee of the Maldives Islamic Bank, claimed that the MIB was not investing in the tourism sector because of certain activities in tourism not approved by Shariah. However, if the MIB found a solution to invest in the tourism sector, the bank would welcome it. He further stated that it represented the duty of academics to propose such a framework. ${ }^{67}$

Amana Takaful Maldives is a foreign company that has been operating Takaful services in Maldives as an agent of the Amana Takaful Sri Lanka. This was the first Islamic Finance Institution established in the Maldives, which occurred in 2003, under the Company Act 1996 (Law No. 10 of 1996). The Company offers a wide range of Islamic Insurance products. These include: individual and business Takaful products. ${ }^{68}$ The company has since changed to a public listed company and its first shares were listed in the Capital Market Development Authority on 17 September $2011 .{ }^{69}$

HDFC is a state owned enterprise created on 29 March 2004 to offer housing facilities. In May 2013, it opened an Islamic window to offer Shariah compliant housing facilities under the name of "HDFC Amana". 70

CMDA is the regulator of the capital markets in the Maldives. ${ }^{71}$ The vision of the CMDA is to develop an Islamic Capital Market parallel to the existing conventional market in the Maldives. There are nine principles approved by

67 Sheikh Fayyad Ali Maniku (A Member of Shariah Committee of the Maldives Islamic Bank), in interview with researcher on 5 December 2013.

68 The products offers by the Amana Takaful Maldives includes; Takaful Dhahana, Takaful Expat, Takaful Travel Plan, Takaful Easy Marine, Marine Hull-Takaful, Hotelier-Comprehensive Takaful, Fire Takaful, Protection and Indemnity Takaful, Total Drive, Business Cover, Takaful My home etc. See Amana Takaful, 'Amana Takaful,' www.takaful.mv, accessed on 22 June 2013.

69 Amana Takaful, 'Amana Takaful,' www.takaful.mv, accessed on 22 June 2013.

70 Housing Development Corporation, 'Housing Development Corporation,' Housing Development Corporation, www.hdfc.com.mv, accessed on 22 June 2013.

71 Capital Market Development Authority website, www.cmda.gov.mv, accessed on 22 June 2013. 
the Shariah Council of the Authority. ${ }^{72}$ Looking into these principles and the terms used by the Shariah Council of the CMDA, it is presumed that these resemble the Malaysian framework more than all others. Simmons and Simmon recommended the Malaysian model for the Maldives șukūk Market. However, they noted that there were a number of legal regulatory obstacles to the issuance of $s u k \bar{u} k$ in the Maldives. These include: the ability to use bankruptcy remote special purpose vehicle, land transfer taxes and the recognition of trust and beneficial ownership under the Maldivian law. However, there are contractual solutions for this in their view. They suggested that in the absence of a local Special Purpose Vehicle (SPV) framework; the best șukūk structure would be șukūk al-murābahah and șukūk al-wakālah in the local market in the Maldives. $^{73}$

In terms of challenges, the Maldives faces and shares most of the common problems that arise within the Islamic financial industry throughout the world i.e. a lack of a comprehensive legal framework, expertise and awareness. Additionally, the scope of Islamic investment remains very limited as the major economic activities rely on tourism industry which, the Islamic banks are reluctant to invest in because of the unconformity with the tenets of Islam in regards with alcohol and pork trades. To cater for these issues further studies need to be conducted taking international experience and best practices into account.

\section{CONCLUSION}

This paper highlights the influences of Islam in the legal system and reformation of the laws in the Maldives. With the establishment of the first Constitution in Maldives in 1932 which declared Islam as the official religion of the country, the subsequent changes to the Constitution has retained this essence as part of the legal reform that governs the country. In this aspect, the most significant constitutional reform was the Constitution of Maldives, 2008 which was introduced with the democratization of the governance such as the separation

72 The principles approved by the Shariah Council includes; musharak, mudāabah, murabahah, qard hasan, istisnā', bay' salam, bay' bithaman ajil (BBA), ijārah and ijārah thumma al-bay". There are structuring Supplementary Principles. These includes, bay' dayn, bay' muzyadah, kafälah, haqh al-tamalluq, hibah, hiwālah, ibra', rahn, șukūk, ujrah, wakālah and ithifaq dhimni. See Capital Market Development Authority website, www.cmda.gov.mv, accessed on 22 June 2013.

73 Simmons \& Simmons, 'The Report on Developing a Sukuk Market in the Maldives,' www.cmda.gov.mv, accessed on 22 June 2013. 
of the powers, creation of various independent institutions and safeguarding human rights which are subject to the tenets of Islam. Also, gaining credence from Article 10 of the Constitution which stipulates Islam to be the religion of the State, the onus on the State to ensure that the fundamental tenets of Islam be adhered to in governance of the country is one that is duly addressed by the fact that Maldives is a Constitutional Supremacy.

Even though the influence of Islamic principles is widely seen in the legal sytem and reform that has taken place till today, there exists room for further research and studies in the academic arena. This would aid in finding solutions to issues such as the reluctance of Islamic financial institutions towards investing in sectors such as tourism, owing to the noncompliant nature of certain aspects of the sector which forms the backbone of the economy of the country.

\section{REFERENCES}

Abdullahi, A., Islamic Family Law in a Changing World: A Global Resources Book (London: Zed Book Ltd., 2002).

Al-Suood, H., The Maldivian Legal System (Male': Maldives Law Institute, 2014).

Amana Takaful, ‘Amana Takaful,' www.takaful.mv, accessed on 22 June 2013.

Ameen, M., Dhivehi Rajjeyge Qanun Asasige Hayath (Maldivian Constitutional History) (Male': Novelty Printers \& Publishers, 1970).

Bank of Maldives, 'Islamic Banking,' Bank of Maldives 'website, https://www. bankofmaldives.com.mv/islamic-banking, accessed on 23rd July 2014.

Capital Market Development Authority, 'Capital Market Development Authority,' www.cmda.gov.mv, accessed on 22 June 2013.

Department of Judicial Administration Maldives, "Justice Statistics Report," http:/judiciary.gov.mv/viewer.html?file=/documents/Statistics/2014/ 2014draft.pdf, accessed on 26 $6^{\text {th }}$ April 2016.

Hornby, A. S., \& Wehmeier, S., Oxford Advanced Learner's Dictionary (Oxford: Oxford University Press, 1995).

Housing Development Corporation, 'Housing Development Corporation,' Housing Development Corporation, www.hdfc.com.mv, accessed on 22 June 2013.

Ibrahim, M. \& Karim, M., 'Research Guide on Legal System and Research of Maldives,' GlobaLex, http:/www.nyulawglobal.org/globalex/ Maldives.html, accessed on $26^{\text {th }}$ April 2016. 
Kamali, M. H., 'Are the Hudud Open to Fresh Interpretation?' Islam and Civilisational Renewal (ICR), 1/3 (2010).

Maldives Hajj Corporation, 'About Maldives Hajj Corporation,' http://mhcl. mv/about, accessed on 28 April 2016.

Maldives Islamic Bank Pvt. Ltd., Maldives Islamic Bank Annual Report. (Male': Maldives Islamic Bank Pvt. Ltd., 2011).

Maldives Islamic Bank Pvt. Ltd., 'Maldives Islamic Bank,'www.mib.com.mv, accessed 22 June 2013.

Maldives Islamic Fiqh Academy, 'Maldives Islamic Fiqh Academy's Resolution No. IFA/2010/01,' http:/www.islamicaffairs.gov.mv/dh//f/ figh.php?pageNum_rsN=1\&totalRows_rsN=13, accessed on $23^{\text {rd }}$ April 2016.

Maldives Monetary Authority, 'Maldives Monetary Authority,' www.mma. gov.mv, accessed on 22 June 2013.

Maloney, C., People of the Maldive Islands (New Delhi: Orient Longman, 1980).

Ministry of Islamic Affairs, Ministry of Islamic Affairs' Regulation No. 2011/ R-40 (Male': Ministry of Islamic Affairs, 2011).

Nasheed, A.M., 'Salient Features of the Maldivian Family Law,' Maldives Law Review, 1 (2013), 17-28.

Robinson, J.J., 'Islamic Foundation calls for death sentence if apostate fails to repent,' Minivan News, http://minivannews.com/politics/islamicfoundation-calls-for-death-sentence-if-apostate-fails-to-repent-7606, accessed on 3rd July 2013.

Simmons \& Simmons, "The Report on Developing a Sukuk Market in the Maldives," www.cmda.gov.mv, accessed on $22^{\text {nd }}$ June 2013.

The Commonwealth Secretariat Website, 'Commonwealth Country ProfileMaldives,' http://commonwealthofnations.org/yb-pdfs/maldives country_profile.pdf, accessed on $23^{\text {rd }}$ April 2016.

The People's Majilis, Dhivehi Rajjeyge Qanuni Hayath (The Maldivian Legal History) (Male': The Parliament House, 1981).

UN General Assembly, 'Report of the Special Rapporteur on the Independences of Judges on Lawyers,' Mission to Maldives, Gabriela Kanul (New York: United Nation, 2013). 


\section{Cases}

Aseeth Thaufeeq v. Maldives Election Commission, 2011/SC-E/07 (2011).

\section{Statutes}

Maldives Family Act (Law No. 4 of 2000), Section 3. (2000). Male': Government of Maldives.

The Constitution of the Republic of Maldives 2008. (2008). Male': Government of Maldives.

Religious Solidarity Act (Law No. 8 of 2004). (2004). Male': Government of Maldives.

Religious Solidarity Act, First Amendment (Law No. 8 of 2014). (n.d.). Male': Government of Maldives.

\section{Interviews}

Husnu Al-Suood (the former Attorney General of Maldives), in interview with researcher on 9 December 2013.

Sheikh Fayyad Ali Maniku (A Member of Shariah Committee of the Maldives Islamic Bank) in interview with researcher on 5 December 2013. 
Jurnal Syariah, Jil. 26, Bil. 1 (2018) 71-98 